\title{
POLITICAL AND SOCIAL VULNERABILITIES IN THE CONTEXT OF THE REFUGEE CRISIS 2011-2016: THE ARAB SPRING AND THE ROLE OF THE MEDITERRANEAN SEA
}

\author{
Toader FLUTUR, PhD \\ National University of Political Science and Public Administration \\ Bucharest/ Romania
}

\begin{abstract}
The issue of uncontrolled migration has produced an institutional transformation of the European Union, dictated by the need to find solutions to new challenges. The reform of migration and asylum policy had to enter the European public agenda at an accelerated pace and political leaders had to find the common will to create the right legislative framework to respond to the migration crisis.

The most important migration route preferred by refugees and economic migrants, is the Mediterranean Sea which in recent years has experienced the most intense human trafficking but also the most deaths in such a short time. As a result of the popular riots in North Africa and the Middle East in 2011, the deteriorating political and social situation in the countries of origin, more and more citizens have left their native places in the hope of ensuring a better life in the European Union.

In order to support the structural reforms needed by the two areas and even physical reconstruction if we refer to the Syrian case, the European Union must show active involvement and a coherent plan to curb the fluid sources of migration. Supporting the reconstruction of foundations or strengthening institutions, investment in aid programs to stimulate economies and strong agreements with the governments of the states of the Middle East and North
\end{abstract}


Africa are just some of the measures that the European Union should take swiftly.

Keywords: migration; conflict; Middle East; the European Union

\section{INTRODUCTION}

"History is a fluid study, where things just seem safe and properly ordered geographically". William Hardy McNeill (Kaplan 2014, 84)

The Mediterranean Sea, known in the Romance languages and as the "sea between the lands", played a central role in European culture, politics and economy, but also in areas on opposite shores. Intensely disputed, the Mediterranean has been a place where European, Asian and African civilizations meet for centuries and precisely through these multiple interactions between peoples with such different religions and cultures, with different levels of development and political systems, the role and influence of the Mediterranean will occupy a dominant place in the European Union's migration policy.

For a long time, the Maghreb has been considered an "Imperial caprice" of Europe, but today, the question is more and more whether it is an imperial failure given the migration crisis and the difficulties encountered in controlling it. However, any crisis also opens up a window of opportunities and, in the case of the European Union, this crisis can be utilised by establishing stronger regulations on legal migration, controlling and combating illegal migration, and by strengthening cooperation with the governments of the countries in the area concerned. In this way, the Mediterranean could be a factor of cohesion rather than division in the near future, in the sense that since the decolonization it has been a natural barrier between democratic and prosperous Europe and politically disintegrated North Africa, which is partially anarchic and poor (Kaplan 2014, 208). Maps can be dangerous tools but are also essential to understand the dynamics of regional and global policy. "On the relatively stable 
foundation of the geography, the pyramid of national power is lifted," Hans Morghentau wrote (Kaplan 2014,65). The national power of the Member States of the European Union has been gradually weakened at an individual level but incorporated and multiplied by the European institutions and its mechanisms which have strengthened the Union's dominant position in the Mediterranean and the Middle East.

The popular riots that shook the Middle East autocracies in 2011 and the economic degradation in those areas generated one of the largest exoduses of this era and reached its peak in 2015-2016. The waves of migrants that have taken the path of Europe have posed important challenges to the institutional and material capacity of the Member States to receive and integrate such a large number of people in such a short time. We will see how the "reheating" of the Middle East is having an effect on the regional security complex where the European Union plays a major role.

\section{THE MEDITERRANEAN SEA - AN INVISIBLE BORDER BETWEEN CIVILIZATIONS}

The Mediterranean is the southern border of the European Union and has been the most strategically, economically and religiously disputed area throughout recent history. The Mediterranean Basin was the cradle of Judaism and Christianity, but also a center of Islamic life, allowing for multiple disturbances in the area, as well as important influences (Friedman 2016, 265). What happens on any of the shores of the Mediterranean generates an influence on any other shore and the first to understand this were the Romans who called the Mediterranean Sea "Middle Sea" or "Mare Nostrum" as the center of gravity of the imperial roman system. In the migration crisis which began in 2011, the Mediterranean Sea was the main transit route for migrants but also the place where the most deaths occurred in their efforts to reach one of the shores of the European Union.

From a political point of view, the Mediterranean can also be regarded as the silent actor in the complex equation of adapting the most appropriate measures 
to rescue those who are really in need at the same time as measures to combat trafficking in human beings trying to take advantage of a favorable humanitarian context.

The appreciation of historian Fernand Bradel that "Mediterranean civilizations are united by the movement of people, the relationships they build and the routes they follow", thus sharing a common destiny, it is still supported today but by disproportionate economic and politico-social arguments (Khanna 2008, 167). North Africa has seen an accelerated economic development in recent decades, but the economic ratio and the democratic deficit toward the European Union still remains too wide.

The evolution of the global economy has brought the countries of the world into an unprecedented complex interdependence by creating the levers for welfare but also causing increasingly difficult problems and crises that governments have to manage (Biró 2013, 85). The combination of migratory pressures - due to different demographic growth and unequal distribution of poverty (and resources), coupled with the social consequences of an ageing working population, are significant reasons for transforming European migration policy and the European Union, being the only supranational entity able to find suitable solutions to this crisis by cooperation with immigrants' states of origin and taking into account the capacity of member states to assimilate economically, culturally, educationally and institutional new populations, it will be the heart of the relationship of the regional security complex and be able to manage the crisis with one voice (Brzezinski 2005, 163). Otherwise, the decisionmaking fragmentation through political dissensions within the Union will lead to weakness in the region and, consequently, an increased deficiency in crisis management of any kind.

Estimates show that by 2050, Europe will lose $24 \%$ of the working young population and that the number of those over 60 years will increase by $47 \%$ in a severe demographic decline compared to Asia, Africa and the Middle East (Kaplan 2014, 207-08). Data for the Middle East and North Africa show instead a $10 \%$ increase in the young population (25-29 years old) with the current pace of migration. (World Bank 2019). The interpretation of this data shows the upward path that migration will take from population-growing areas to the 
European Union which is in demographic deficit. If we analyse the situation strictly from an economic point of view, we can discuss of a win-win situation where the economic stability of the Union can be maintained by attracting external labour, and on the other hand, the young generations who aspire to a safer and more prosperous future, will be tempted to achieve them in the European Union. In terms of the cultural mix and the "clash of civilizations", the effects are complex and highly unpredictable. A faulty integration policy of such as that of France in the 1950s and 1960s years focused strictly on economic criteria and needs has started to have an effect on societal security 30 years later. The economic strength of the European Union has attracted migration from all shores of the Mediterranean, but not all European countries had experienced cultural or economic exchanges with other nations so diverse culturally, religiously and ethnically. The foundation of the European nation States was related to a common-sense derived from a common language, history and culture, which could not be achieved by a legal transcript of citizenship alone but required a longer adaptation. In this context, the European Union has promoted multiculturalism which allowed immigrants, although some of them had become citizens to remain different and to be tolerated by local culture and implicitly by the authorities. The problems and social tensions with a cultural argument appear paradoxically between the newcomers and the poorer indigenous population who feels insecurity, and less between the rich social classes that have guaranteed both freedom and the diversity of both social categories. (Friedman 2016, 270-2)

The post-war European architecture was strongly influenced by the way the European States behaved during the Second World War in the paradigm of total War. The entire force of the society - industrial, social, military (Friedman 2016, 133) - was engaged in war and the subsequent consequences have led to major changes both in European policy and in the social, economic and military relations that Europe was going to cultivate.

The 1950s determined the independence of several African States around the Mediterranean under the influence of France, which was now concerned about the objectives and the role that it was going to play in the newly established European Economic Community. In this context, Algeria-much disputed within 
France but also by the Algerian nationalists, has gained independence on this unstable background in which General de Gaulle decided to direct French efforts toward the economic and political reconstruction that was severely affected. The consequences of this independence were the waves of immigration, where only in the first months after the release, about 900.000 French Algerians emigrated, mainly in southern France (Abulafia 2014, 651-2).

In the conditions of depopulation by reducing natural growth and taking into account a favourable economy, African immigrants who came to European cities on the shores of the Mediterranean have become a cheap labour force in the 2000s and were valued to fill that shortage of people working in agriculture in particular. In fact, it is the Mediterranean countries that have faced the waves of migrants through the associated territories and the proximity of transport routes, which has led to a debate on the inequality of pressure, but also a farreaching legislative reform if we mention only the Dublin II Agreement and its revised form (Abulafia 2014, 659).

From an economic point of view, the sale of trade links between North Africa and Southern Europe shows a positive-sum game. The natural gas network that weakens dependence on Russian gas for Europe and increases the Maghreb budget and food exchanges are just two examples that strengthen mutual gain (Khanna 2008, 167). However, at the political level, the process by which the Maghreb region is developing has many syncopes. In addition to corruption and the democratic deficit, the geostrategic and economic influence of the European Union does not fully reflect the expectations from the African shores of the Mediterranean. In fact, fifty years ago, Toynbee noted the needs of Maghreb farmers who did not "dream of pacts and treaties, but of pumps and tractors", and the situation has not changed much today (Khanna 2008, 168). Therefore, a starting point for effectively limiting migration can be made through a financial support plan for the area that provides the necessary impetus for sustainable development along the lines of pre-accession countries, or why not, even along the lines of a Marshall Plan for North Africa.

The European Union is the "winning card" for most people in North Africa, however the attractiveness of the European Union differs from what it offers for the Balkans and here is limited to economic aspirations and thus to improving 
life. The European political leadership must completely reform the equation of relations with North Africa to integrate the best form of cooperation between migration, trade development, the energy issue and political stability in the area. For example, the Maghreb, while reporting high unemployment, is suffering from the skilled workers crisis, which shows a dysfunction between local government policy and the real needs of societies (Khanna 2008, 168). Thus, the European Union can contribute with policy experience in the field of labour and social justice, through training programs, limiting interest in economic migration and helping local development.

\section{RELIGION'S ROLE IN THE ECONOMICAL AND POLITICAL EVOLUTION FROM BOTH SIDES OF THE MEDITERRANEAN SEA}

The global inequality is revealed mostly because some states took advantage or not of the industrial revolutions from the 19th and 20th century. The developmental differences that have emerged from this capacity to adapt to technical revolutions are strongly connected to the innovations and methods of political and social organization that they have set and outlined as the model of prosperity that we can find today in the European Union (Acemoglu and Robinson 2016, 277). An extremely important role in the different evolution of states or geographical regions was played by the relation to religion, or in other words said, by the separation of religion from the state. European secularism has allowed for accelerated development through the systematic institutional organization while Islam has remained in the shadows and boundaries set by holy law.

Niall Ferguson confirms in his work "The Great Decline" that the divergences of economic, political and social development were based not on racial primordiality as insisted by certain Eurocentric theories of past centuries, nor on the "luck" of Europeans to find the more fertile lands overseas, neither geographical positioning nor imperialist character, but the institutions. 
Institutions determine certain modern historical configurations and dictate the pace and nations' level of well-being. Douglas North, John Wallis and Barry Weingast pointed out that Western European states were the first to overcome the character of the limited state based on social relations organized on a personal and dynastic line and adopted the model of the state with free or liberal access as it would be known later. This was built around a decentralized government, a legislative system where the rule of law was the main reporting and property, impartiality and equality rights began to become absolute guidelines for the proper functioning of the state (Niall Ferguson 2014, 33-4). On the other side of the Mediterranean Sea, after the decolonization stage, except for a few states, the Middle East and North Africa areas returned to a triad that proved to be very inefficient: a social and political organization through dictatorships with strong religious accents, lack of competitive economic reforms and an increase in ethnic fragmentation largely inherited from an "unfortunate" drawing of the borders of the Western Powers over time.

The role of politics in the prosperity or poverty of a nation is determined by how it influences the legislative architecture according to which the institutions function and implicitly the life of the individuals in that nation. Political institutions decide the distribution of power in society and contribute to the establishment of equity or inequity through pluralism and unrestricted access through inclusive political institutions or absolutist limitations and the concentration of power in a small group through extractive political institutions (Acemoglu and Robinson 2016, 89).

The political architecture of both the Middle East and North Africa has allowed the perpetuation of autocratic leaders who used the "religious weapon" at the expense of updating institutions to meet the real needs of the population until extreme poverty escalated as in the case of widespread uprisings known by the name of "Arab Spring".

The modern European colonization of the Arab world was not done in the name of Christianity, but actually in the name of technical progress and economic development. Thus, Europeans were looking to export the values that were "freeing" and "civilizing" to modernize institutions (Luizard 2008, p. 58). However, this process was not successful and with the withdrawal of Western 
powers or the loss of their influence, the new power was imposed by force and also by invoking religious legitimacy. Political Islam emerged in the twentieth century as a movement of protest and reaction to the humiliations caused on the battlefields and as a result of socio-economic discontent in recent history.

The political component of Islam was an attraction for its followers not because they had a Koranic education in their childhood, but because it represented a symbol of opposition to the West and the first aboriginal ideology in the Arab world (Mansfield 2015, 397).

In the Islamic world, the process of secularization followed a behavioral path with certain common elements: hierarchical imposition from leaders to citizens; authoritarian processes of modernization that take place within the single party doubled by the cult of personality of the leader; a dominant role of the army. But the foundation on which secularization, highlighted between state and religion should have been based, did not occur (Luizard 2008, 201). Kemal's Turkey was the first to open the trend in this regard, followed by Pahlavi's Iran, Amanollah's Afghanistan and a quarter of a century later by the Republic of Tunisia, Egypt, Iraq and Syria. The pace of the secularization process was extremely slow, doubled by the inefficiency of implementing democratic reforms in complete contradiction with the dictatorial interests of the leaders of those states.

\section{THE ARAB SPRING: A GENERATION'S REVOLT}

The accelerated interdependence of the last 70 years has contributed to increasing short-term sensitivity and long-term vulnerability for the European Union. Sensitivity shows the degree of the states' exposure to a change in a particular area (Nye Jr. 2012, 72). The Arab Spring has demonstrated in the simplest way that political and social events outside the borders of the European Union create side effects in a relatively short time on the social and even physical security of the Union through the waves of immigrants that have tried and those that have managed to cross its borders, attracted by the welfare status and the conditions of the social system in general available on the territory of the European Union. As the migration crisis from the Middle East and North Africa 
to the European Union shows no signs of ending, for both the understanding and the adaptation of the Union's policies, religious, political and social knowledge about the area are considered to be indispensable.

The history of the Middle East is characterized by religious struggles through which multiple entities seek to legitimize power and dominate the regional political scene. In Arab-Islamic society, religion is a means of solidarity between people and influences the events of economic and political life in an exhaustive way. In addition to the economic and social underdevelopment of the area, the Middle East shows an anti-globalization trend caused by the fear of aggression that can be produced against the Arab-Islamic culture and identity, against the system of specific values based on the holy law and which are seen as altered by "the danger of globalization" (Bolborici 2016, 71). However, the globalization of communication itself and access to technology that has called into question the stability of several authoritarian regimes in the Middle East and North Africa by opening a new stage of collective awareness of the political and social organization imposed by authoritarian leaders.

History books have noted that World War I was sparked by the Sarajevo bombing of Archduke Franz Ferdinand and his wife, Duchess Sophie Albina Chotek, by the Serbian extremist Gavrilo Princip. In 2010, after the authorities confiscated the unauthorized vegetable stall of a Tunisian - Mohamed Bouazizi, the young university graduate set himself on fire in public in protest (Mansfield 2015, 467). Even if this comparison does not contain elements in common with all points of view of the analysis, in terms of impact, we can say that just as a hundred years ago a seemingly isolated event triggered a real World War, so did the case of the street vendor that caught fire in Tunisia set in motion a revolution in the Middle East that spread at an accelerated pace. Obviously, behind both the outbreak of the First World War and in the case of the revolution known as the "Arab Spring" there were multiple elements that smoldered and were waiting for a "spark". Nationalisms, imperialism, the arms race and the lack of communication between states and empires provoked and prepared long before the "Great War", while the "Arab Spring" was preceded by stifled or partially successful uprisings such as the one in Iraq in 2005, economic and social discontents, the effects of authoritarian regimes that impoverished the 
population access to technology and pressure from new generations attracted by transnational identities.

The 26-year-old Tunisian - Mohamed Bouazizi - a veggie seller in a market in Sidi Bouzid who refused to offer bribes to local authorities because he could not afford a license, being the only breadwinner for his widowed mother and his six brothers by resorting to a method of extreme self-arson protest in front of the offices of the Regional Council, has unleashed unprecedented and somewhat surprising national support for most of the autocratic leaders of the Middle East (Ramsbotham, Woodhouse and Miall 2018, 137). Thus, in less than a few weeks, an isolated event in a dull country - Tunisia, managed to provoke protests throughout North Africa and the Middle East, questioning the fragile regimes of authoritarian leaders in the Arab world in an unprecedented domino effect (Mansfield 2015, 467).

Globalization and the development of communications have reheated geopolitics, making the world map more interconnected than ever. A conflict in Syria will have effects on the Muslim community in France and fuel terrorist actions just as an interethnic conflict in one state can trigger regional conflicts elsewhere in the globe with common interests or using the pretext of supporting those interests to achieve their own goals. (Kaplan 2019, 259).

The main achievement of the Arab Spring was that, for the first time in the history of the states in the area, votes now seemed to be preferred instead of bombs and the local population was left to look for concrete solutions to their problems (Mansfield 2015, 471). Although the appearance of democratization was quickly curbed in most states by popular uprisings, the spark had been ignited and the signal had been triggered by a young generation with access to knowledge of Western models of a socio-economic organization through technology. Naturally, any autocracy seeks to preserve its power and the advantages with which it was built and the removal of political leaders could be a violent and even escalating challenge in open military conflict if we are referring to the Syrian case.

Although the expulsion of Ben Ali from Tunisia in January 2011 had opened the box of hope for Egyptians, Lebaneses, Syrians or Libyans, the reality revealed a lack of cohesion between populations of different ethnicities and especially an 
asymmetric confrontation between government forces who aimed to defend the autocratic regime at any price and the civilian population "armed" with slogans and demands for democratic reforms.

It should be clarified that, although the educated elites claimed to have initiated the protests, the spark of rebellion was produced by the anger of the peripheries where the range of the regimes was weakened and the forces of various groups prevailed. In Tunisia, the young Bouazizi who set himself on fire was in the town of Sidi Bouzid, $260 \mathrm{~km}$ from the capital Tunis.

In Libya, protests in the marginalized east reached the capital Tripoli only six months later, and in Syria demonstrations against its government were more like rural clashes that many Sunni townspeople did not pay attention to. It was only after seven months that the situation become more complicated for the Assad regime when the outskirts of Damascus demanded that the autocrat leader relinquish power. This detail demonstrates both the bought obedience of the population towards the autocratic leaders in the more economically developed cities (the centre of the political regime), and especially the despair caused by the minimal material shortages on the periphery (Mansfield 2015, 473).

\section{THE RESISTANCE OF AUTOCRATIC POWER}

The evolution and success of the protests in the Middle East and North Africa have taken different stages. At the height of the protests, Syrian leader Bashar alAssad was not at all impressed by the vehement street protests shouting in unison "ya Doktor, Ijak al-Dour" - Doctor, now it's your turn! ", On the contrary, he instigated the people even more by arresting children participating in the protest and killing other civilians. The popular protests in Syria, which began in mid-March 2011, were based on the population's demand for massive reforms. They were met with violent repression by the Syrian regime, which the EU strongly condemned and imposed sanctions two months later, including an embargo on weapons and equipment used for repression, a freeze on assets and a ban on travel against the ones involved in repression (including of Bashar al- 
Assad himself) and the suspension of bilateral cooperation programs. Even though the sanctions imposed have extended to the oil trade area, the conflict has seen a continuous escalation and a volume of emigration that has never been seen before in Europe during such a short period of time. The ensuing civil war in Syria between supporters of the Assad regime and the reformed army of the majority of the Syrian population triggered the largest refugee crisis in Europe and causing European Union states to adapt to a situation they had never encountered before and which was not covered by any Treaty related to the functionality or organization of the European Union.

In Cairo, leader Mubarak chose to send troops of thugs to disperse the crowd to the detriment of the reforms the society needed and in Libya, Muammar alGaddafi sprayed protesters in Benghazi with anti-aircraft fire (Mansfield 2015, 471-2). These violent reactions against their own population show how strong and long-lived the autocracy was and, implicitly, how important it is for these political leaders to defend their power.

Where protests have succeeded in overthrowing autocratic regimes, the power vacuum has been filled by chaotic centrifugal forces lacking democratic experience and a unified vision of leadership. Each liberated city or neighbourhood has formed its own militia, looting official trade routes and consolidating alternative smuggling routes. A new political and military order was far from being achieved as children ran tanks and looted and destroyed in groups - beltagiya. However, the rivalries within societies seized by the dream of democratization and socio-economic reforms were fueled by the desperation to control the state. The reformers clashed with the revolutionaries, the peasants with the city workers, the federalists with the centralists, the exiles with those who had endured the traumas caused by totalitarian regimes, and the many Islamist movements that had been oppressed until then initiated ethnic liberation measures by allocating an important religious nuance (Mansfield 2015, 473-4).

In Morocco, for example, King Mohammed VI quickly understood the extent of the demands of the population in the context of the Arab Spring and held quick elections to strengthen his power disguised by the entry in the government of a loyal Islamist movement - Justice and Development, which also decided the 
Prime Minister. Even if the general impression that the monarch wanted to leave in order to dissipate the social pressure, respectively that he renounces infallibility and a series of constitutional powers, in reality he kept an essential role in the presidency of the Council of Ministers, of the Council of Ministers. Security but also control over the secret police forces and intelligence services (Mansfield 2015, 480). And in this case, we notice an institutional deficiency typical of authoritarian regimes: the propensity to retain the benefits of power and lack of civic reaction, the timid or delayed support of the international community completed the picture of an opportunity for real reform.

Iraq, Tunisia, Egypt, Yemen and even Libya have partially experienced relatively peaceful transitions to democracy, in part through the help of old military forces and through external support. Nevertheless, lacking a democratic institutional memory, the new forces that took control imagined that the winner would take everything, ignoring the need for a system of verification and equilibrium that would prevent abuses of absolute power and generate a new form of abusive government. Replacing an autocratic regime with one of religious fundamentalism will not be able to meet the demands for profound reform that the young of the new generation hav (Mansfield 2015, 482-3).

We must mention that the Arab Spring also meant an opportunity to occupy positions of regional power for non-Arab actors Iran, Turkey and Israel, who intervened in the battles fought not by armies, but by supporting dissidents according to interests, by providing money or supporting media propaganda, by encouraging religious controversy aimed at dividing or aid hidden under humanitarian pretexts. Turkey has seen major successes in trying to expand its influence through Erdogan's new attitude of challenging his government's "noproblem" conservative policy and supporting popular Islamist movements instead (Mansfield 2015, 490-93). In addition to that, Turkey has gained influence in relation to the European Union through a blackmail policy on the issue of immigrants and maintaining control of the route of human flows through the Turkish state.

Undoubtedly, the development of the Internet and television on a global scale has helped to lift many people out of their isolation and connect them to knowledge, to models of democracy that, in return, open the way to 
mobilization, to social and political activism. In the case of the Arab Spring, the emergence of the concept of political awakening of the Middle East and the connection to the international community of the young generation brought with its methods of street protest against political power and social pressure tactics inspired by this technological connection using unprecedented forms of civic and political activism in the history of the region (Brzezinsky 2013, 30). It is still too early for a global analysis of the effects of the Arab Spring, given that political change and democratic behaviour require a long time horizon.

\section{CONCLUSIONS}

In conclusion, we can say that the wave of protests during the Arab Spring that should have laid the foundations for democracy quickly turned into take-over of power by the same autocratic forces disguised as reformers but who in reality buried the real motives and the honest intentions of the Middle Eastern population to have less corrupt governments capable of concrete democratic reforms (Welsh 2016, 50). The importance of "waking up" the younger generation must be followed by the collective perseverance, the contribution of the international community in supporting the democratization process and by a halt to the exodus of the hard core which can be considered to be a real pressure force to shake up the preservation of the power of autocratic leaders. The Mediterranean Sea will remain the most fluid channel of migration to the European Union, given the fragility of the Middle East and North Africa, and especially the strong economic attraction and proximity of the member states of the European Union. The response of the European authorities to the migration crisis has been prompt and effective for the most part, managing to limit the flow of illegal migration by up to $90 \%$. The role of the new European institutions that emerged as a result of the need generated by the migration crisis has shown that there are both cohesion and common objectives within the European Union in managing the physical security of the Union's borders.

Effective management of the migration crisis entails an active involvement of the European Union in the countries of origin of migrants. Viable strategies for 
resolving crises and conflicts in the Arab world must necessarily take into account elements and different procedures from the Western world. George Irani pointed out that at the level of the states in the Middle East there is a triple axis of how conflicts can be resolved, as follows: wasta involving patronage based on mediation, sulh- a model of rituals involving commitments and understandings and musalaha- reconciliation. (Ramsbotham, Woodhouse and Miall 2018, 402-3).

The European Union's migration policy has been based almost exclusively on track-one diplomacy by establishing direct agreements and negotiations with the governments of the relevant states. But these methods had been proved to be insufficient and the role of the European Union can be complemented by informal diplomacy which includes the support of local leaders but also a more active involvement in the economic support of migrants' countries of origin.

\section{REFERENCES}

- Abulafia, David. 2014. Marea Cea Mare: O istorie umană a Mediteranei. (The Great Sea: A Human History of the Mediterranea.) Bucharest: Humanitas.

- Acemoglu, Daron and James A. Robinson. 2016. De ce eșuează națiunile. Originile puterii, ale prosperității și ale sărăciei. (Why nations fail. The origins of power, prosperity and poverty). Bucharest: Litera.

- Biró, Daniel. 2013. Relațiile Internaționale Contemporane: Teme centrale în politica mondială. (Contemporary International Relations: Central Themes in World Politics). Iași: Polirom.

- Bolborici, Ana-Maria. 2016. Diplomația Uniunii Europene și criza din Orientul Mijlociu la inceputul secolului al-XXI-lea. (European Union diplomacy and the crisis in the Middle East at the beginning of the 21st century) Iași: Institutul European.

- Brzezinsky, Zbigniew. 2013. Strategic Vision. America and the Crisis of Global Power. New York: Basic Books. 
- Brzezinski, Zbigniew. 2005. Marea Dilemă: a domina sau a conduce. (The big dilemma: to dominate or to lead). Bucharest: Scripta.

- Ferguson, Niall. 2014. Marele Declin. Cum decad instituțiile și mor economiile. (The Great Decline. How institutions decay and economies die). Iași: Polirom.

- Friedman, George. 2016. Puncte de presiune: despre viitoarea criză din Europa. (Pressure points: about the future crisis in Europe). Bucharest: Litera.

- Kaplan, Robert D. 2014. Răzbunarea Geografiei. (Revenge of Geography). Bucharest: Litera.

- Kaplan, Robert D. 2019. Revenirea Lumii lui Marco Polo: război, strategie și interese americane in secolul XXI. (The Return of Marco Polo's World: War, Strategy and American Interests in the 21st Century). Bucharest: Humanitas.

- Khanna, Parag. 2008. Lumea a doua. Imperii și influență în noua ordine globală. (The second world. Empires and influence in the new global order). Iași: Polirom.

- Luizard, Pierre-Jean. 2008. Modernizarea țărilor islamice. (Modernization of Islamic countries). Bucharest: Artemis.

- Mansfield, Peter. 2015. O istorie a Orientului Mijlociu. (Mansfield, Peter. 2015. A history of the Middle East). Bucharest: Humanitas.

- Nye Jr., Joseph S. 2012. Viitorul Puterii. (The future of power). Iași: Polirom.

- Ramsbotham, Oliver and Tom Woodhouse and Hugh Miall. 2018. Contemporary Conflict Resolution. London: Polity Press.

- Welsh, Jennifer. 2016. The Return of History: Conflict, Migration, and Geopolitics in the Twenty- First Century. Toronto: House of Anansi Press.

- World Bank. 2019. "Population ages 25-29, male (\% of male population) Middle East \& North Africa." Accessed on July 4, 2019. https://data.worldbank.org/indicator/SP.POP.2529.MA.5Y?locations=ZQ. 